\title{
A ESCOLHA DE AGAMEMNON: NOTAS SOBRE UMA TRAGÉDIA DE ÉSQUILO ${ }^{1}$
}

\author{
Rafael Faraco Benthien ${ }^{2}$
}

\section{Dos limites da ação}

Entrar em contato com uma obra tão distante de nós como a tragédia grega revela-se um desafio no mínimo instigante, marcado pela sutil tarefa de pensar aquilo que já foi pensado. E agindo assim, no desvelamento de um outro pensar, qualquer indivíduo também corre o risco de contemplar a si próprio. Tal como nos antigos ritos de iniciação, o ato de ler o transporta para fora de seus limites. Quando encerra-se o período de isolamento, é hora de voltar para assumir uma nova postura frente ao seu mundo.

Para o leitor contemporâneo, a tragédia grega pode assumir pelo menos duas facetas interessantes. Podemos congelá-la através do estigma de um texto sombrio, onde escondem-se segredos indecifráveis por trás de cada verso; e, diferentemente desta primeira impressão, é também possível cultivar um sentimento maior de angústia, oriundo da percepção de que é possível entender(-nos em) tal texto, apenas faltam-nos as palavras certas. Como, por exemplo, devemos "rotular" a tragédia grega? Teatro, arte, literatura, ou algo mais? Passando por alguns maus bocados, o leitor teimoso é forçado a perceber que tais manifestações ou categorias modernas sequer existiram entre os gregos antigos. Tudo não passa de um equívoco, uma falha em várias perspectivas contemporâneas de análise.

Essa angústia, já outrora sentida por alguns, foi essencial à abertura de caminhos para que hoje pudéssemos nos aventurar a recuperar parte daquelas antigas experiências presentes originalmente na tragédia. Aristóteles, Shakespeare, Racine, Goethe, Hölderlin, Nietzsche, entre outros, fizeram leituras canônicas destas obras e restauraram alguns de seus elementos primordiais através de novas criações. Não obstante, eles não criaram tragédias gregas. Trata-se de momentos diferentes, outras formas de estar no mundo. Mesmo assim a discussão aqui apresentada dialoga com esta tradição, pois é na angústia da modernidade que o passado trágico torna-se passível de ser procurado.

Antes de cristalizar o texto trágico na sua diferença, é mais interessante questionar o sentido desta alteridade para o homem contemporâneo. Daí a escolha temática deste artigo: a ação dos personagens da tragédia. Algumas perguntas então se impõem: o que significa agir hoje? E qual o limite e o sentido de tais ações? Trata-se de questões cuja dimensão assusta, uma vez que hoje tanto se fala de uma

\footnotetext{
' O presente artigo é uma versão levemente alterada do trabalho individual desenvolvido no PET-História da Universidade Federal do Paraná durante o ano 2000. Este mesmo texto foi apresentado durante a IV Congresso de Estudos Clássicos, realizado em Ouro Preto durante o mês de agosto de 2001.

${ }^{2}$ Graduando em História e bolsista PET/SESu UFPR.
} 
desestruturação dos vários paradigmas que até então guiavam nosso agir. No passado, outros homens se ativeram a questões parecidas de outras maneiras. Talvez a razão pela qual é difícil respondê-las hoje esteja no fato de que concentramo-nos muito em pensá-las em termos positivos. E isso aponta para este princípio tão caro ao historiador, de que uma outra situação vivida no passado pode ajudar, pela sua diferença, a enriquecer o entendimento de nós mesmos, de nosso presente.

Do pequeno número de peças clássicas que chegaram às nossas mãos, optei aqui por centralizar minha análise no Agamemnon de Ésquilo. Significativa dentro da obra deste autor trágico, a ação dos personagens de Agamemnon pode ajudar-nos a perceber uma série de signos que transitavam no contexto de sua criação. Precedendo tal estudo de caso, foram levantadas algumas questões estratégicas para que o leitor se habitue ao tema.

Agora passemos para o trabalho mais complexo: discorrer sobre a diferença do universo simbólico que permeia tal peça.

* * * * *

Por certo, o substrato simbólico através do qual o homem grego pensa o ato de agir é diferente daquele que temos hoje. Em uma artigo intitulado Esboços da Vontade na Tragédia Grega, publicado em 1972, Vernant lança alguma luz sobre estas peculiaridades, dando-lhes um enfoque psicológico ${ }^{3}$. Diz-nos ele que, ao contrário de nós, os gregos não entendiam o agente como aquele que individualmente segue de acordo com sua vontade. "Livre-arbítrio" e "vontade" são noções muito estranhas aos povos arcaicos. O cosmos não é visto como lugar da realização individual, mas sim como o espaço de encontro de forças supra-humanas. Em parte obscuras aos mortais, elas também influenciam suas vidas.

O homem grego, mesmo após o advento da polis, ainda guarda viva na memória essa presença divina. Quanto mais antigos os relatos mais claro é tal fato. À sombra das palavras de um Homero, de um Hesíodo e mesmo de um Ésquilo, boa parte das ações aparecem independente do indivíduo que as realiza. E mesmo quando o "direito" ático tenta vincular alguma responsabilidade ao sujeito, ele o faz de uma forma estranha a nossa mentalidade, limitando a liberdade de ação em prol de fatores anteriores e superiores ao agente ${ }^{4}$.

Ao falarmos de liberdade de ação, é importante que o leitor atente também para o sentido arcaico de liberdade. Justamente por não implicar em livre-arbítrio, ele ajuda-nos a entender a relação do homem grego com seu mundo. Como já disse

\footnotetext{
${ }^{3}$ Publicado em VERNANT, J.-P. et VIDAL-NAQUET, P.. Mito e Tragédia na Grécia Antiga. (São Paulo, 1999) pp. 25-52.

${ }^{4}$ Tais como a família, a frátria, os deuses, etc. Para mais detalhes no que diz respeito à ligação entre o direito grego e a ação ver GERNET, Louis. "Droit et prédroit en Grèce ancienne" In:. .Droit et Instituitions en Grèce Antique. (Paris, 1982) pp.7-119. Já para a relação entre os homens e aquilo que lhes é superior ver o primeiro capítulo de DODDS, E.R. The Greeks and The Irrational. (Londres, 1984) pp. 1-27.
} 
Benveniste, lá "cada membro só descobre seu si, no entre si" pessoas e divindades por meio de direitos e obrigações é a única maneira de ser livre. Seu oposto, o escravo, não mantém nenhum laço social - ele é um "coisa", está fora da sociedade. Daí a idéia de que o agir não é um atributo próprio do agente. As obrigações deste para com os homens e deuses restringiram as possibilidades do agir e não a própria vontade. Podemos encontrar nos argumentos de Vernant uma evidência disto, pois este nos mostra que mesmo um século depois da morte de Ésquilo, quando tais antigas concepções de mundo já apareceriam muito fragmentadas, Aristóteles ainda não consegue formular uma teoria geral da ação, em que possam ser distinguidas a intenção e a escolha. Ele fixa a responsabilidade desta ação, vinculando-a a juízos morais. Diz-nos Vernant:

“(...) a causalidade do sujeito, tanto quanto sua responsabilidade, em Aristóteles, não se refere a um poder qualquer da vontade. Ela tem como base uma assimilação do interno, do espontâneo e do propriamente autônomo. Essa confusão dos diferentes níveis da ação mostra que o indivíduo, se ele já assume sua particularidade, se assume a responsabilidade de todos os atos realizados por ele de bom grado, permanece muito fechado nas determinações de seu caráter, muito estreitamente preso às disposições internas que comandam a prática dos vícios e das virtudes, para liberar-se plenamente como centro de decisão pessoal e afirmar-se enquanto autós, em sua verdadeira dimensão de agente."

Ainda segundo Vernant, a atmosfera conceitual que envolve Aristóteles é essencial para se entender o que sentiam os autores trágicos. A diferença, porém, está no fato de que estes últimos não procuraram restringir a categoria da ação ao caráter de cada um. Eles disporiam de pelo menos dois discursos opostos, nos quais os novos valores da polis confrontar-se-iam com as antigas tradições, os antigos deuses com os novos homens. De tal relação surge o homem trágico, vagando em um mundo repleto de contradições ${ }^{7}$.

Porém, essa interpretação da tragédia defendida por Vernant guarda uma simplicidade constrangedora. A demarcação de mundos opostos não pode ser vista como o fim último da tragédia grega. Na maior parte das tragédias estas diferenças são apenas aparentes e o conflito inicial ruma, mesmo que através da morte, para uma solução. Através de sua produção, os autores trágicos passam a buscar algo que dê sentido a seu mundo e, como não poderia deixar de ser, eles o fazem na recuperação parcial e na releitura de suas tradições.

Em Ésquilo, as ações dos personagens não se anulam mutuamente em um jogo de soma zero. A seqüência de faltas cometidas não constata apenas erros de comunicação entre os personagens. Elas dão um sentido maior para a tragédia

\footnotetext{
${ }^{5}$ BENVENISTE, É.. O Vocabulário das Instituições Indo-Européias. Vol.1. (Campinas, 1995) p. 317.

${ }^{6}$ VERNANT, J.-P. et VIDAL-NAQUET, P.. Mito e Tragédia (...). Op. Cit. p. 41.

${ }^{7}$ Ver "Tensões e Ambigüidades na Tragédia Grega". In:. Id. Ibid. pp.7-24.
} 
esquiliana, pois é o sofrimento do protagonista trágico que o prepara para a compreensão do universo do qual ele faz parte. Albin Lesky refere-se a essa trajetória quando esquematiza a "moral" presente nos textos de Ésquilo: ação do homem - culpa - expiação no sofrimento - compreensão e conhecimento ${ }^{8}$. Enfim, a ação do protagonista lança-o, através de seu sofrimento, rumo ao entendimento de seus próprios limites, seu lugar no mundo. Trata-se, como veremos mais tarde, de uma jornada rumo a um estado de liberdade primordial, onde homens e deuses possam novamente encarar-se frente à frente e reforçar as antigas alianças de novas formas.

Porém, por si só, este comentário equipa-nos precariamente com conceitos para abarcar a dinâmica deste "aprendizado". Miha sugestão é de que falta aqui algo que dê conta de explicar o valor que o ato de agir possui nestas sociedades arcaicas. Para este caso específico, tomo de empréstimo à antropologia francesa um conceito que permanece muito caro à academia: a dádiva. Mauss em seu Ensaio sobre a Dádiva já a havia apresentado como uma espécie de fato social total ${ }^{9}$. Tratava-se de uma forma de circulação de serviços e mercadorias típica de sociedades arcaicas, onde se mesclam e são um só o social, o político, o econômico, o religioso, entre outros.

Por trás destes elementos básicos escondem-se outros fundamentais. Para começar, esse tipo de troca estabelece vínculos que, por sua vez, devem ser sempre renovados. Ou seja, a retribuição é um dever. E não se trata apenas de um negócio entre os homens. Os deuses relacionam-se entre si e com os mortais segundo os mesmos princípios. Além disto, esta prática também cria uma estranha noção de riqueza: rico é aquele que mais distribui aquilo que tem - quanto mais generosidade, mais alianças. Daí decorre que aquele que acumula somente para si corre o risco de tornar-se um escravo de suas posses, despertando a ira dos que anteriormente as ofereceram. A estas práticas de distribuição (queima) de propriedade, Mauss dá o nome de Potlatch. E em último lugar, tudo aquilo que pode ser trocado é dotado de um espírito intimamente ligado ao seu local de origem. É esta força sobrenatural que garante o retorno do favor, uma vez que o espírito dos objetos tende a voltar para onde foram forjados.

Em muitas sociedades arcaicas, a dádiva, sem ser pensada necessariamente como fato social, pode ser percebida como elemento regulador de um certo cálculo. E é possível através desta operação tornar inteligível a ação, torna-se passível de ser executada. Já se falou muito da dádiva na Grécia antiga. Tal lógica aparece claramente em trechos de Homero e vai ter presença garantida em boa parte dos textos gregos, mesmo depois do chamado Período Clássico (séc. V-IV a.C.). Um típico exemplo disto pode ser encontrado na descrição que Detienne faz dos vários

\footnotetext{
${ }^{8}$ Para encontrar estes comentários referentes à tragédia esquiliana ver LESKY, Albin. A Tragédia Grega. (São Paulo, 1996) pp. 91-139.

${ }^{9} \mathrm{O}$ ensaio citado encontra-se em MAUSS, Marcel. Sociologia e Antropologia. Vol.2. (São Paulo, 1974) 94
} 
ritos iniciáticos da Atenas Clássica ${ }^{10}$. Lá, para serem considerados cidadãos, os jovens eram sucessivamente apresentados à comunidade ateniense através de festins que envolviam primeiramente a família, depois a frátria, e por fim seu demo. Em todas estas ocasiões os deuses estavam presentes e a eles eram feitas oferendas, no sentido de reforçar os laços entre os novos membros da comunidade e as antigas forças protetoras da região. E por falar em festividades, Gernet coloca no mesmo patamar os ritos de iniciação e as festas sazonais, no que se refere aos circuitos de dádiva e contra-dádiva e chama-os inclusive de Potlatch ${ }^{\prime \prime}$. Criando a partir deste mesmo solo simbólico, estes elementos arcaicos vão se fazer presentes nas tragédias gregas, dando sentido a boa parte do que aparece lá. O Agamemnon de Ésquilo não é uma exceção. Partamos então à caça destes indícios.

\section{Agamemnon ou o cálculo trágico}

O Agamemnon de Ésquilo foi concebido como a primeira peça de uma trilogia: a Oréstia, possivelmente encenada em meados do séc. V a.C.. Ao longo das três tragédias podemos acompanhar a trajetória do ramo da família dos Átridas reinantes sobre Argos. Do retorno de Agamemnon de Tróia, sua morte pela mão da esposa, à vingança de seu filho e à redenção deste último: eis os pontos culminantes de tais narrativas. Atentemo-nos basicamente nos dois primeiros eventos, ambos presentes na primeira peça.

Durante dez anos Agamemnon manteve-se longe de casa, Argos. Em sua terra poucas são as notícias sobre seus sucessos e muitas são as intrigas. O coro de anciãos teme que algo ruim possa acontecer com seu rei (ävoķ) e, a partir daí, inicia uma longa apresentação dos eventos que levaram-no a partir. Há dez anos Príamo reinava sobre Tróia. E então, enquanto hospedava-se em Esparta na casa de Menelau (o irmão de Agamemnon), levou-lhe a mulher, Helena. O äv $\alpha \xi ̧$ de Argos e irmão do ofendido, Agamemnon, procura juntar seus aliados para comandá-los na guerra que deveria corrigir esta ofensa feita a Zeus Xênios - protetor das leis referentes à hospedagem. Porém, antes da partida, um presságio se faz presente: duas aves de rapina devoram um lebre prenhe e indefesa. Calcas se oferece como intérprete e revela que Menelau e Agamemnon são as aves, e Tróia, a lebre. Tal banquete sinistro perturba Ártemis, que cobra como reparação a vida de Ifigênia, filha de Agamemnon. Só através deste sacrifício o vento voltaria a favorecê-lo, e assim possibilitaria ao a̋v $\alpha \xi$ de Argos juntar-se à frota aquéia. Entre sacrificar a própria filha ou abandonar os aliados, Agamemnon "escolhe" a primeira opção. Tão logo o vento começa a soprar ele parte, deixando todos receosos quanto ao futuro.

\footnotetext{
${ }^{10}$ DETIENNE, Marcel. "Negócio dos homens, negócio dos deuses". In:. Os Deuses Gregos. (São Paulo, 1990) pp. 233-244.

"GERNET, Louis. "Frairies antiques". In:. Anthropologie de la Grèce Antique. (Paris, 1986) pp.29-82.
} 
Nestes dez anos de ausência de Agamemnon, um clima sombrio paira sobre sua casa. A morte da filha e a subseqüente partida do assassino dissolveram o respeito e a reverência da mãe e da esposa representada por Clitemnestra. Se a guerra não desse cabo do rei, ela mesmo o faria. Eis que o sinal de fogo que simbolizaria a vitória dos aqueus torna-se visível no horizonte. Um misto de euforia e descrença toma conta da população, só dissipado com a chegada da mensagem que anunciava o retorno triunfal de Agamemnon. Este não tarda a chegar, trazendo consigo um despojo de guerra: Cassandra, uma sacerdotisa de Apolo. Clitemnestra age rapidamente para dar cabo do marido, e o faz levando-o para dentro de seu palácio. Antes mesmo da morte de Agamemnon, Cassandra tenta mostrar aos anciãos o que o futuro reserva a ele (e também a ela). A cegueira e a passividade do coro culmina com a morte do rei e da sacerdotisa, seguida pela usurpação do trono por Egisto, parceiro de Clitemnestra. Frente à alegada ilegitimidade desta ação, só resta ao coro prever a vingança de Agamemnon por seu filho, Orestes.

*** *

Se existe algum evento fundamental à unidade da peça, dentre aqueles mencionados acima, é o momento da "escolha" de Agamemnon. Salvar a filha ou abandonar os aliados? As opções, por mais que nos pareçam estranhas, são colocadas à prova, e o futuro do protagonista depende muito de sua maneira de agir. Vejamos este trecho no original:

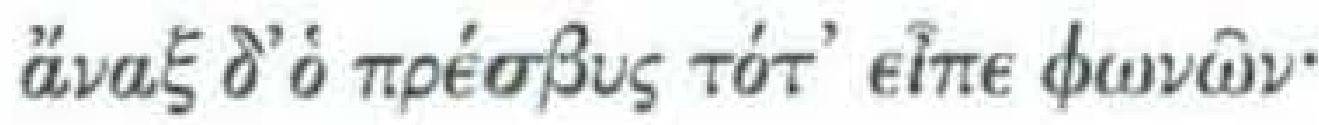

205

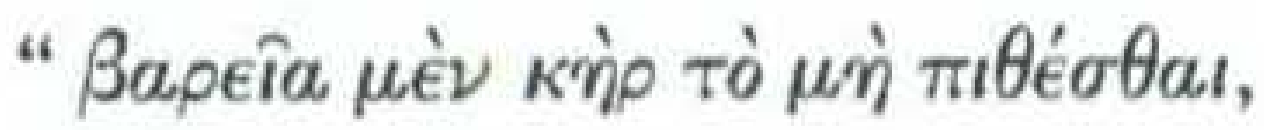

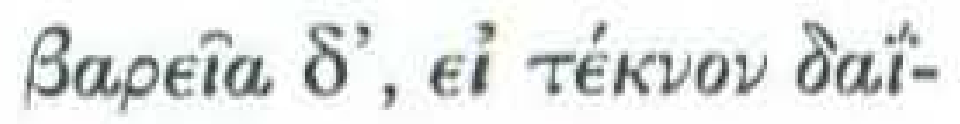

$\xi \omega$, dó $\mu \omega \nu$ ä $\gamma a \lambda \mu a$,

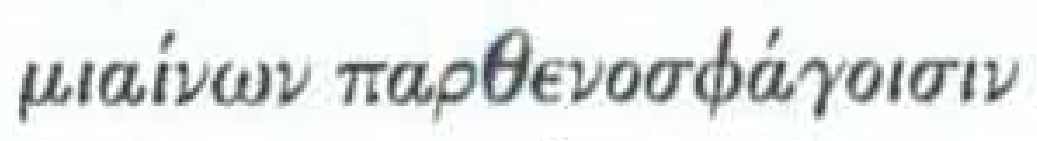

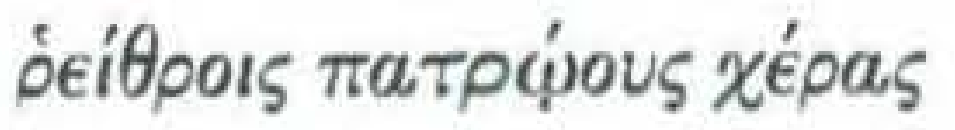

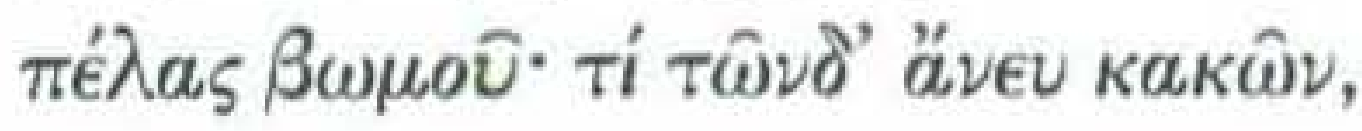

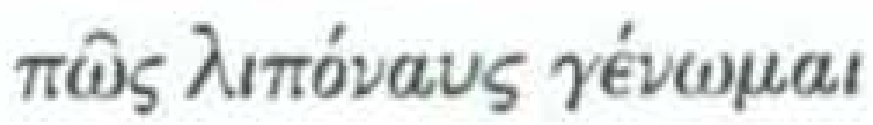

$\xi \nu \mu \mu a x i a \varsigma \dot{a} \mu a \rho \tau \dot{\nu} \nu$;

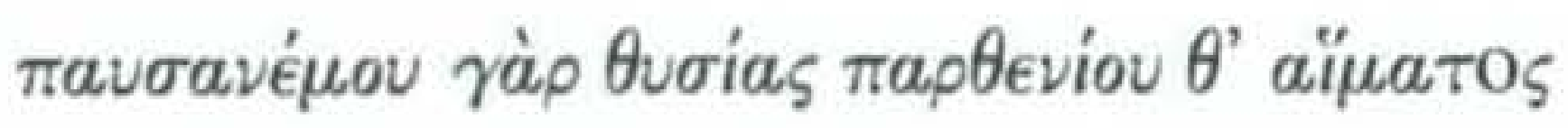

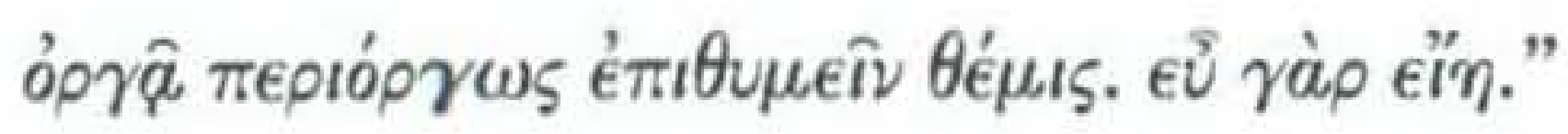

"Será atroz o meu destino se resisto", falou o mais idoso dos reis; "será atroz, também, matar minha filha, adorno, encantamento do palácio meu, manchando minhas mãos de pai com sangue do sacrifício de uma virgem inocente. Qual dos caminhos me trará agora mágoa menor? Será possível nesta hora abandonar de vez a expedição traindo tantos e tão prestes aliados? De certo está com eles a justiça se querem decididamente $o$ sacrifício capaz de os ventos nos trazer, propícios, embora tenha de jorrar sangue puro! Que possa ser para o bem. 
Este pequeno trecho ${ }^{12}$, por si só, traz-nos uma série de pistas importantes para o entendimento da peça. Agamemnon aparece aqui, realmente, frente a dois caminhos irreconciliáveis. Ou salvar a filha e abandonar os aliados, ou sacrificá-la em favor de seu compromisso com eles. As partículas $\mu \epsilon \dot{\varepsilon} . . . \delta$ ' presentes nas linhas 206-207 dão este toque drástico à escolha, funcionando como uma espécie de expressão de alternativa. E é a partir daqui que tem início o "cálculo trágico". A necessidade de agir leva o protagonista a pesar suas duas possibilidades. Independentemente de qual seja a decisão tomada, ele percebe o quanto é difícil ( $\beta \alpha \rho \varepsilon i \alpha)$ escolher entre dois caminhos que lhe parecem faltosos. Se opta por sacrificar a filha é porque partir com seus aliados pareceu-lhe coincidir com a vontade dos deuses, algo passível de ser desejado e executado.

Tal vontade divina Agamemnon vê nas figuras de Zeus, Ártemis e, mais adiante na peça, Apolo. Se ele pensa em partir para enfrentar Páris não é apenas por capricho, mas para reparar a falta deste às leis de hospedagem instituídas pelo próprio Zeus. Pelo menos é assim que o protagonista vê suas ações, acreditando que sejam benéficas. Todos os avisos futuros de nada valerão. Daí, como veremos adiante, sua cegueira quanto ao macabro pedido de Ártemis, que ele passa a ver como bom e inevitável.

Porém, independente de todos estes sinais, Agamemnon momentaneamente reluta em sacrificar Ifigênia. Afinal de contas, ela é sua filha ( $\tau$ é Kvov), portanto uma $\delta \omega^{\prime} \mu \omega \nu$ ä $\gamma \alpha \lambda \mu \alpha^{1 !}$. A tradução de Herbert Smyth sugere que esta expressão indica a glória de um domos (casa), mas também sua riqueza e suas jóias, como sugere Anatole Bailly ${ }^{14}$. Mas, parece-me que tais traduções esvaziam um pouco o significado original do termo. Gernet nos fornece vários indícios em que ä $\gamma \alpha \lambda \mu \alpha$ aparece envolto em um outro tipo de valor que não o honorífico e/ou econômico, mas basicamente "mítico"15.

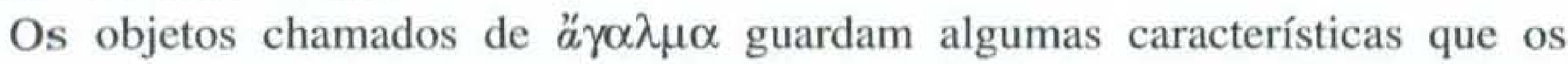
distinguem dos demais. Não são propriamente moeda de troca, pois são portadores de certos preceitos religiosos, mas sinônimo de uma riqueza estranha a nós. Como já disse antes, tal riqueza não é concebida como um mecanismo de acumulação - tratase de uma forma de estabelecer laços duradouros. A força destes objetos reside precisamente aqui, pois são instrumentos privilegiados para trocar favores com os deuses. Mesmo na época clássica, quando tal palavra parece ter seu significado fixado como oferenda a eles, vários contemporâneos de Ésquilo nos trazem uma série de exemplos curiosos de objetos encantados. Desde Homero, ninguém nunca

\footnotetext{
${ }^{12}$ AG. 205-215. Texto grego estabelecido por Herbert Weir Smyth (Londres, 1999). Tradução para o português de Mário da Gama Kury.

${ }^{13} \mathrm{Ag} .208$.

${ }^{14}$ BAILLY, Anatole. Dictionnaire Grec Français. (Paris, 2000) p.5.

${ }^{15}$ Ver GERNET, Louis. "La notion mythique de la valeur en Grèce". In:. Grèce Antique. (Paris, 1986) pp. 121-179. Anthropologie de la
} 
deixou de falar, com freqüência, em anéis mágicos e vasos de ouro, cetros e assim por diante. Tudo isto é parte do imaginário grego.

Por se tratar de uma sociedade altamente hierarquizada, a riqueza inerente ao

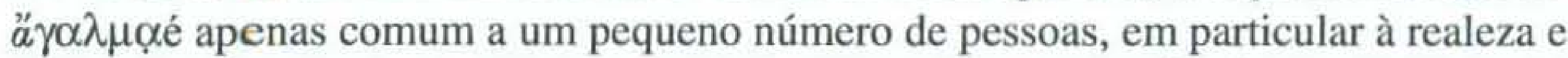
à aristocracia (helênica). Podemos então pensar a filha de um äv $\alpha \xi$ como um tipo de ä $\gamma \alpha \lambda \mu \alpha$ ? Parece-me que sim, pois é através de seus filhos e filhas que os vários soberanos procuram restabelecer antigos laços de amizade e formar novos. Os deuses também entram neste circuito de trocas, pois de seus desígnios depende a manutenção da posição hierárquica dos mortais. Deixando tal jogo de lado, por uma suposta ordem divina, Agamemnon opta por matar sua filha, e, é importante salientar, o faz antes que ela se torne mulher. Ainda virgem, Ifigênia não teve a possibilidade de entrar no circuito de dádivas. Não pôde casar e gerar descendentes. Ela ainda não fora totalmente incorporada à cultura. E sua morte aparece como uma metáfora do que por pouco não atingiu toda a casa de seu pai.

Onde terá então Agamemnon errado? Ainda é cedo para respondermos tal pergunta. Não obstante, é importante frisar neste ponto que: ao agir com o intuito de sacrificar sua filha, ele pensava estar honrando Zeus. Da mesma forma acreditava estar reforçando os laços de amizades com outros aqueus e, ao mesmo tempo, satisfazendo Ártemis. Aquém de sua relutância, esta escolha parecia a certa, mas reservou-lhe um futuro negro. O cálculo trágico, aquilo que leva o protagonista a agir, revela-se aqui como uma espécie de prisão. Agamemnon confia muito na sua astúcia, ao ponto de confundi-la com sua hybris (orgulho) sem o perceber. Agindo assim, o que ele consegue é romper suas ligações com seus mais importantes aliados. Volto a afirmar que tal destino não se explica apenas por um conflito entre dois mundos (divino/humano, passado/presente). As ações de protagonista não se dirigem contra os deuses, mas ignorando a dimensão de suas forças. Não podemos perceber a extensão desta queda sem antes nos atermos ao estatuto de Agamemnon. Aquilo que ele é, dará a dimensão de suas obrigações para com os homens e deuses. Nas páginas que se seguem também serão propostos alguns sentidos para a participação dos personagens de Ifigênia, Zeus, Ártemis, e mesmo Clitemnestra. Comecemos por Agamemnon.

\section{$* * *$}

Agamemnon e Menelau recebem de Ésquilo o título de äv $\alpha \xi$. Quais as implicações disto? Um pista interessante reside na constatação de que eles não são os únicos a serem assim chamados. O deus Apolo, por exemplo, aparece na mesma peça agraciado com este mesmo título ${ }^{16}$. Isto nos lança às concepções de realeza da Grécia arcaica, onde o estatuto do ăv $\alpha \xi$ não é restrito aos mortais. O que torna alguém um rei são certos poderes místicos e atitudes que podem ser encontradas tanto em deuses como entre os homens. O poder místico de produzir vida e prosperidade são algumas das atribuições mas importantes que acompanham a

\footnotetext{
${ }^{16} \mathrm{Ag} .513$

98
} 
legitimidade do äv $\alpha$ ğ. E estas duas prerrogativas estão ainda inter-ligadas a outras, em particular à honra $\left(\tau \iota \mu \eta^{\prime}\right)$ e à instituição do Potlatch. Para melhor ilustrar isto, vejamos um trecho da tragédia em que o coro apresenta-nos Menelau e Agamemnon:

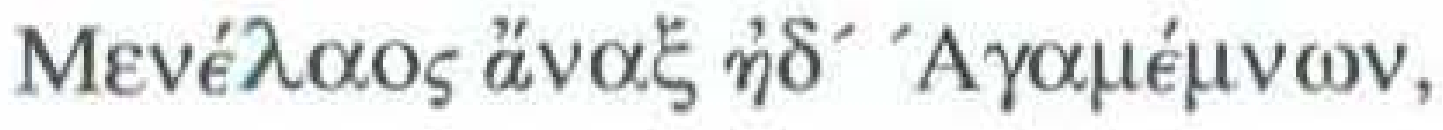

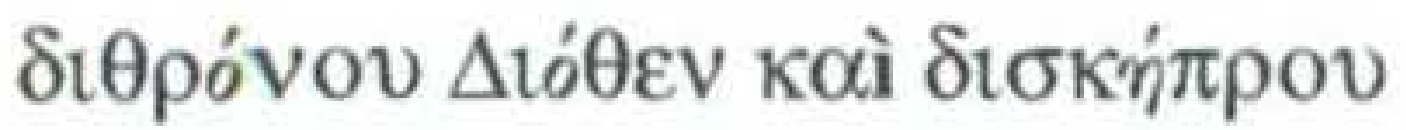
$\tau \mu \hat{\eta} s$
Rei Menelau e seu valente irmão, rei Agamêmnon, dois tronos e dois cetros dons de Zeus.

Os dois irmãos são aqui mostrados como unidos por honrarias pela graça de Zeus. Já em Homero, e isto Ésquilo parece manter, a $\tau \mu$ ஸ́ é uma prerrogativa divina, concedida por Zeus como sinal de amizade ${ }^{17}$. Tal noção de honra se diferencia de outras formas de prestação, como o géras. Da forma como a define Benveniste, ela não envolve apenas "uma prestação material ou ocasional dos homens ao soberano ou a um herói” ${ }^{18}$, mas também uma extensa circulação de riquezas. É importante salientar que a honra é da mesma natureza destas riquezas, ou seja, são dádivas. Porém a honra guarda uma especificidade: por ser concedida por Zeus, ela figura como uma espécie de dom primordial. É o que une deuses e reis através de laços de amizade. Também cabe ao rei, por sua vez, ligar-se aos outros mortais, concedendolhes riquezas e serviços em troca de lealdade. Criam-se portanto laços de reciprocidade. Ele deve dar-lhes prosperidade, lavouras fartas, bens materiais e,

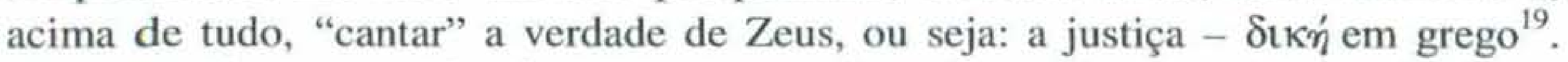
Uma vez aberto este circuito, o cosmos vai sendo rapidamente hierarquizado. A mesma ordem é então instituída entre os deuses ou entre os homens. É justamente aqui que se casam os princípios da honra e do Potlatch. Estas práticas e prerrogativas reequilibram o mundo, pois transformam o conhecimento de si no reconhecimento do lugar de cada um deve ocupar - lembrem-se aqui do conhece-te a ti mesmo de Delfos. Não obstante, essa organização do mundo não se dá de forma "pacífica"; é a tensão que unifica o mundo.

\footnotetext{
${ }^{17}$ Veja-se por exemplo Il. II, 197.

${ }^{18}$ BENVENISTE, E.. O Vocabulário das Instituições Indo-Européias. Vol.2. (Campinas, 1995) p. 52.

${ }^{19} \mathrm{Na}$ Grécia arcaica alguns personagens tinham prerrogativas muito parecidas, entre eles o poeta. Porém, a verdade vinculada a esta figura não se fia em nenhum tipo de metafísica, ou seja, ela não se opõe absolutamente à mentira. Pensando nisto, uma das possíveis tradução para tal palavra seria "desvelar". A verdade está naquilo que é contado e feito por pessoas com tais prerrogativas. Como muito poucos detinham o privilégio da fala e da ação, isto não era visto como um grande problema. Para mais detalhes sobre este assunto ver DETIENNE, Marcel. Os Mestres da Verdade na Grécia Arcaica. (Rio de Janeiro, 1988).
} 
No trecho colocado acima, além das referências explícitas à honra (e implícitas

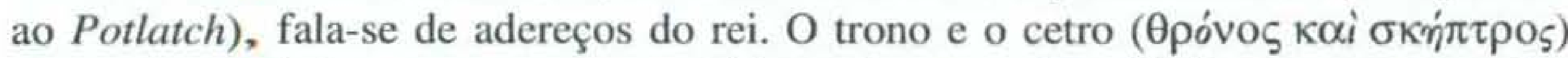
aparecem aqui não apenas como metáforas de um poder objetivamente dado, eles mesmos encarnam-no. O cetro de Agamemnon, por exemplo, é um presente dado a seus antepassados por um outro rei: Zeus. O poder divino inerente a ele é o que sustenta os poderes e privilégios de seu portador. A divindade confia-o àqueles que escolheu para falar em seu lugar. Durante muito tempo Agamemnon foi um deles, mas quando Zeus lhe tomou o cetro, em resposta à sua cegueira, a queda se fez inevitável.

Até agora restringi-me a levantar uma série de elementos arcaicos referentes à noção de realeza helênica, ou seja, sobre o äv $\alpha \xi$ e todo o simbolismo que envolve. No entanto esta figura não passa de uma lembrança para os gregos da época de Ésquilo. Não existem mais reis e heróis como existiam outrora. As antigas prerrogativas do soberano passaram então a ser diluídas na Atenas de Ésquilo, através da invenção de um complexo quadro sócio-administrativo. Segundo Vernant isto teria mesmo possibilitado a emancipação de uma esfera de ação e pensamento propriamente político, como o entendemos hoje $\mathrm{j}^{20}$. Pessoalmente acho muito questionável esta afirmação, mesmo assim ela efetivamente reúne um número significativo de argumentos para sugerir-nos uma certa mudança. $\mathrm{O}$ direito de falar, de agir, que até então era direito de uma pessoa, ou mesmo um grupo muito restrito, passa a ser insistentemente questionado. Esta mudança pode muito bem ser associada aos eventos ocorridos durante os sécs. VII-VI a.C. investigados por Mossé: a ação de reformadores como, por exemplo, Sólon e Licurgo, e a instituição de várias tiranias ${ }^{21}$. Tais fenômenos são duas faces de uma mesma moeda.

Trata-se de momentos críticos que evidenciam um processo que já ocorria há tempos. Com o advento da polis amplia-se lenta e irreversivelmente o privilégio da fala e da ação. E eis que o mundo dos deuses torna-se velado ao homem grego. E como poderia ser de outra forma? Não existem mais os antigos äv $\alpha$ para mostrar a seus súditos a justiça. Porém os signos que acompanhavam estes reis continuaram existindo, e ainda persistiriam por muito tempo. Este simbolismo dará sentido a boa parte do universo trágico, moldado por e para um novo homem. De forma significativa, boa parte das tragédias que nos chegaram trazem como personagens principais velhos signos de poder (äv $\alpha \xi$ e $\beta \alpha \sigma \lambda \lambda \varepsilon u ́ \varsigma$ ), deuses, semi-deuses e também mulheres. Frente às novas possibilidades de pensamento, o lugar e o sentido destes antigos reis e deuses são repensados. Não haveria lugar melhor para discutir o estatuto da mulher, "mostrá-la, confundi-la e depois reencontrá-la", como diz Loraux ${ }^{22}$.

\footnotetext{
${ }^{20}$ VERnANT, J.-P.. As Origens do Pensamento Grego. (São Paulo, 1996)

${ }^{21}$ MOSSÉ, Claude. Grécia Arcaica: de Homero a Ésquilo. (Lisboa, 1989). Capítulos VI a X.

${ }^{22}$ Sobre os signos que acompanham as mulheres na tragédia ver LORAUX, Nicole. Maneiras Trágicas de Matar uma Mulher. (Rio de Janeiro, 1988) p.12.
}

100 
Do universo dos homens ao obscuro mundo dos deuses. A Oréstia de Ésquilo parece sugerir este caminho, do qual o Agamemnon é apenas o início. Nas linhas anteriores tentei mostrar como o estatuto de ăv $\alpha$ gexplica-nos muito sobre a conduta do protagonista da tragédia. Para ele era fundamental reforçar sua posição frente aos deuses e aliados, comandando-os em uma luta contra Tróia. Um mal-entendido, fruto de um desconhecimento de si mesmo. Como já foi dito antes, os homens não se confrontam com os deuses, apenas desconhecem a natureza de suas relações com eles. Daí a importância de atermo-nos à presença das divindades na tragédia aqui estudada. Zeus e Ártemis dão um significado a esta dimensão obscura do divino. Ifigênia, apesar de mortal, também só ganha sentido quando pensada dentro de uma esfera sagrada. É rumo a esta obscuridade que convido o leitor a acompanhar-me agora.

\section{$* * *$}

A hospitalidade, uma instituição cada vez mais estranha a nós, era dotada de um sentido especial entre os gregos. Convidar um alguém estranho à sua comunidade para dormir sobre sob seu teto, provar do seu vinho e de sua comida não era só uma atitude normal aos gregos, ela era mesmo essencial. Também esta prática é pensada através de uma complexa rede de dádiva e contra-dádiva. Uma vez aceito o convite, o hóspede liga-se a seu bem-feitor através de uma clara relação de amizade. Esta amizade podia ser compartilhada tanto entre mortais como entre os deuses. Relatos que apresentam tais ocasiões são encontrados mesmo após a morte de Ésquilo. A chegada de divindades "estrangeiras", por exemplo, era tão comum na Atenas do séc. V a.C. que muitos cidadãos hospedavam-nas em suas casas, até que suas próprias moradas fossem construídas ${ }^{23}$.

Que outra divindade poderia proteger esta instituição senão Zeus? O zelo com a honra e a justiça estão intimamente ligados à hospitalidade no pensamento arcaico, pois é o mesmo princípio que os guia. E indo de encontro a isto surge Páris. Ele, um äv $\alpha$ gde Tróia, ao levar consigo Helena, fez explodir algo próximo a uma guerra cosmológica. Não foram apenas os homens que lutaram - algo que seria inconcebível -, mas também os deuses.

Tróia, como qualquer outra cidade, mantém laços de amizade com deuses e homens. A história do rapto de Helena não deve ser encarada como algo que evoca uma moral como a concebemos hoje. Páris não comete um "pecado capital" quando rompe com Menelau. Seu desejo de possuir Helena era apenas mais significativo do que manter sua aliança com os aqueus. Deste ato não decorreu necessariamente sua derrocada. A Ilíada de Homero, que os autores trágicos parecem conhecer bem, traz a história de uma batalha com altos e baixos para os dois lados, só decidida no final,

\footnotetext{
${ }^{23}$ Platão, por exemplo, no primeiro livro de sua República, ambienta as discussões entre Sócrates e seus interlocutores, nas festividades que aconteciam em torno da chegada de uma divindade trácia. Outra ocasião semelhante é vivida por Sófocles em aproximadamente 420 a.C., só que desta vez é o próprio poeta trágico que recebe o divino Esculápio em sua casa. Este último relato aparece descrito em LESKY, Albin. Op. Cit. p. 144-145.
} 
por poderes superiores aos homens (em particular a interferência do próprio Zeus, que até então mantinha-se neutro).

Da mesma atmosfera de tensão surge o Agamemnon de Ésquilo. Aqui também o destino do protagonista não está traçado desde o começo, mas vai se definindo ao longo da própria peça. Ao guerrear contra Tróia, todos os aqueus estavam frente a inúmeros e fortes inimigos, os aliados de Páris. A cada um dos lados cabia conseguir uma retratação do inimigo, ou uma vitória. A falha de Agamemnon e de seus aliados foi ter feito disto um pretexto para destruir Tróia completamente. Não fora apenas Páris o prejudicado: guerreando durante a noite, os aqueus assassinaram boa parte dos súditos deste, e o restante transformaram em cativos. Ora, esta ação foi extremamente desrespeitosa aos deuses, posto que TODOS aqueles mortais relacionados com as divindades protetoras de Tróia foram aniquilados. Alguém haveria de pagar este imenso prejuízo. Agamemnon tem uma clara idéia daquilo que presenciou, ele mesmo refere-se ao combate em Tróia como assassínio $^{24}$. É curioso como esta percepção não se restringe apenas ao rei, pois o coro de anciãos de Argos, em um trecho anterior, anuncia o perigo que acompanha a destruição de uma cidade. Ela anuncia a possível (e iminente) destruição da terra natal do conquistador ${ }^{25}$.

A mesma relação que Agamemnon tem com a destruição de Tróia, é também aquela que o prende à filha. Não por acaso, o assassínio de Ifigênia e de Tróia estão ligados. O elo aqui não poderia ser outro: Ártemis. No seu duplo aspecto de caçadora dos bosques selvagens e jovem donzela, ela é a protetora das fronteiras entre os mundos. Vernant refere-se a esta deusa com as seguintes palavras.

"Ela (...) está intimamente ligada a ritos de passagem. Ela age de maneira a estabelecer uma delimitação precisa entre meninos e meninas, jovens e adultos, animais e homens, para que se possam articular corretamente a castidade que a donzela deve observar e o casamento que realiza a condição adulta da mulher, as pulsões da sexualidade e a ordem social, a vida selvagem e a vida civilizada" ${ }^{26}$.

$\mathrm{Na}$ tragédia de Ésquilo, o aparecimento desta divindade pauta-se por estes termos. A deusa teme pelo futuro de Tróia. A destruição deste lugar aparece aqui como a violação de uma parthenos, uma virgem. E como tal, ela não pode ser concebida dentro de um padrão honrado e, até certo ponto, civilizado de comportamento. Em relação a Ifigênia, é importante ressaltar que a prática do sacrifício, como era feita em sociedades arcaicas, coibia a utilização de oferendas não pertencentes ao mundo humano ${ }^{27}$. Animais selvagens não são passíveis de ser sacrificados, tampouco virgens. Elas ainda guardam uma presença forte do selvagem, do inviolável. Não por acaso, na tragédia de Ésquilo, os atributos da filha de Agamemnon são da mesma ordem dos de Ártemis. $\mathrm{O}$ autor relaciona refere-se às duas através da palavra $\alpha \gamma v o ́ s$ (refere-se ao sagrado, ao território do inacessível ao

\footnotetext{
${ }^{24}$ Ag. 813-816.

${ }^{25} \mathrm{Ag} .469-474$.

${ }^{26}$ VERNANT, J-.P.. A Morte nos Olhos. (Rio de Janeiro, 1991) p.25.

${ }^{27}$ BENVENISTE, E. O Vocabulário (...). Vol. 2. Op. cit. p.223-243

102
} 
homem) ${ }^{28}$ Ora, sendo assim, a "escolha" pela morte da filha aparece então como uma

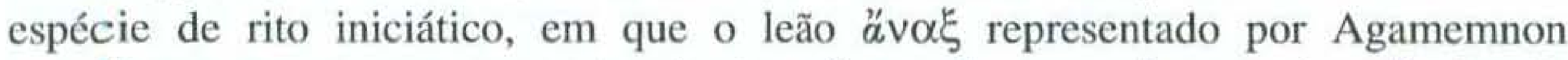
transforma-se em uma serpente. As transfiguração concede ao rei o direito de abandonar ALGUMAS obrigações que a sua posição lhe impõe, permitindo-lhe, por exemplo, derrotar Tróia durante a noite (ao guerreiro honrado só é permitida a luta diurna).

Em A Caça e o Sacrifício na Oréstia de Ésquilo, Vidal-Naquet vê toda a trama da trilogia através das metáforas do sacrifício, da iniciação e da caça ${ }^{29}$. Segundo ele, ao sacrificar sua filha, Agamemnon penetrou um universo bárbaro, onde a morte é o único caminho possível. De leão a serpente, o rei passou também de caçador a caça. E essa não seria apenas a sina de Agamemnon: toda sua família - Clitemnestra e Orestes - passaria pelas mesmas experiências. Apenas Orestes, por motivos que o autor não deixa muito claro, consegue escapar ao cruel destino.

Apesar de toda genialidade/originalidade do texto de Vidal-Naquet, sua tentativa parece congelar o movimento trágico através do insondável jogo de destino. O destino não está dado desde o começo, e a forçosa aproximação do sacrifício, a caça e a iniciação, não pode ser usada para dar sentido a algo que não existe. Não obstante, há uma relação entre estes três elementos através da dádiva, mas isso não significa que devam ser pensados em conjunto. Como já vimos antes, só com a iniciação consumada pelo sangue da filha, Agamemnon pôde partir e lutar como efetivamente ele lutou. Agora a caça e o caçador não são necessariamente opostos. É no mínimo interessante que percebamos o homem trágico como alguém que, metaforicamente, está a caçar seu próprio ser. Ele é caça e caçador ao mesmo tempo. Além disto, tem sempre de lidar com energias maiores que ele. Quanto ao sacrifício, ele se insere na lógica clássica, já descrita por Hubert e Mauss, de estabelecer laços e efetivar pactos (metonímicos) entre os mortais e os deuses.

Através destas três instâncias, Clitemnestra e Agamemnon tentaram levar a cabo seus planos. A transfiguração deste último parece-lhe necessária para manter sua posição frente aos seus aliados. Ele sabe que a guerra o deixará mais vulnerável, pois gerará atrito com uma série de forças aliadas a Páris e também indisposição em seu lar. Clitemnestra, por certo, ressente-se da morte da filha e do abandono do marido. Ela entrará no jogo trágico procurando reunir em torno de si elementos que sustentem sua posição e seu interesse. De tais anseios, frutos de uma visão de mundo particular, os personagens das tragédias procuraram agir. Aí aparece o "calculo trágico" em toda a sua complexidade. Dele depende o contato entre homens e deuses. Tal operação, no entanto, não é livre de equívocos e de ilegitimidades, até porque lida com as ambigüidades de um universo a procura de uma auto-

\footnotetext{
${ }^{28}$ Sobre o sentido arcaico das esferas do "sagrado" o do "profano", ver Id. Ibid. pp. 181-206, com especial atenção para as últimas 4 páginas. Já as referências à $\alpha$ \%o , ver Ag. 135 (relacionado à Ártemis) e Ag.245 (relacionado à condição divina da voz de Ifigênia). Em Ag. 94 também aparece indicando uma esfera propriamente divina.

${ }^{29}$ VERNANT, J.-P. et VIDAL-NAQUET, P.. Mito e Tragédia (...). Op. Cit. pp.101-124.
} 
sustentação. As mensagens divinas, bem como a força da relação entre deuses e homens, são mal calculadas. Falta algo que lhes dê uma medida. Vejamos a seguir dois breves exemplos de como se processa este cálculo no Agamemnon de Ésquilo. $* * *$

$\mathrm{O}$ primeiro destes exemplos refere-se à captura de Cassandra em Tróia e sua subseqüente ida a Argos. Essa aparição é fundamental na obra, pois, na figura de uma sacerdotisa de Apolo, ela dá toda uma dimensão mágica à queda de Agamemnon. Sua ligação com um deus oracular como Apolo, fornece-lhe a possibilidade de prever o futuro. Durante sua breve conversa com o coro tais habilidades ficam claras ao leitor, mas não aos anciãos de Argos. Ao não compreenderem o significado de suas palavras, eles perdem a oportunidade de recuperar a força de seu äv $\alpha \xi \xi$ e assim, restaurar a justiça que tal figura encarna. Contudo, Agamemnon não a traz de uma terra distante sem procurar vantagens.

Cassandra não é uma simples escrava, mas, na acepção do rei, um rico presente do destino enviado para protegê-lo ${ }^{30}$. Ela representa uma ligação direta com o deus, sua voz na terra. Agamemnon busca desmesuradamente obter esta vantagem para manter-se em sua posição após o grande perigo enfrentado. A falta de medida desta ação reside no fato de a presença de Cassandra ser uma decorrência do assassinato monstruoso de Tróia. Os eventos ocorridos operam também uma mudança nela. $\mathrm{O}$ coro percebe-a como um animal selvagem recentemente capturado

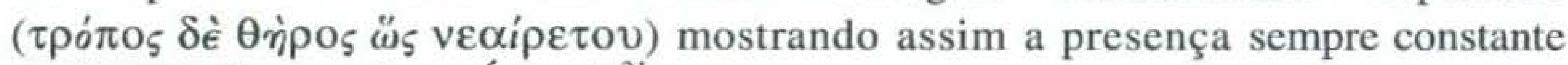
de signos relacionados a Ártemis ${ }^{31}$.

Significativa é também a forma de tratamento dada a Cassandra. Nem Agamemnon, nem o coro consideram-na uma simples escrava, pois não teriam usado derivados de ל̧évo ato de ligar-se a alguém através da hospedagem. Porém tal sentido, como quer a grande maioria dos filólogos, foi substituído por outro: o de estranho, estrangeiro. Das várias vezes em que derivados de Gévos aparecem na Oréstia, Herbert Smyth basicamente os traduz de duas formas. Nas referentes à Zeus como host and guest $\mathrm{e}$ nas demais como estrangeiros. Do duplo significado do termo decorrem pelo menos algumas opções. Em primeiro lugar, se admitirmos a utilização de uma mesma palavra para dar conta de duas idéias diferentes, devemos estar abertos para admitir elementos arcaicos em pelo menos um destes sentidos. E, em segundo lugar, como me parece mais interessante, podemos admitir que Ḱévos e seus derivados tangenciam um mesmo sentido: referem-se a estrangeiros com os quais é possível (e desejável) manter relações. Na continuação de Agamemnon, é sob o rótulo de $̧$ évo que Orestes se apresenta diante de sua mãe para vingar seu pai ${ }^{32}$.

\footnotetext{
${ }^{30}$ Ag. $950-955$.

${ }^{31} \mathrm{Ag} .1063$.

${ }^{32}$ Co. 700-706, para exemplos significativos.

104
} 
A explanação feita acima aponta para a condição especial de Cassandra. Uma prisioneira sim. Mas também uma sacerdotisa de quem se espera uma frutífera aliança. Confirmando tal vantagem da presença de Cassandra para Agamemnon, parece estar o desprezo de Clitemnestra pela estrangeira. Nas poucas palavras referentes à cativa, a mulher do rei parece frisar sua condição de escrava ${ }^{33}$. Mas ela não ignora o perigo que Cassandra representa a seus planos, daí seu empenho em matá-la.

O exemplo de Cassandra aponta para a tensão existente no mundo trágico. Procurando restabelecer e salvaguardar sua posição de äv $\alpha \xi$, Agamemnon empenha-se em trazer para junto de si signos de amizade com os deuses. Paralelamente a isto, levando-nos ao segundo exemplo do cálculo trágico, Clitemnestra procura barrar este intento. Vejamos com mais cuidado uma cena clássica onde ela procura golpear o prestígio de seu marido.

Trata-se do momento seguinte à chegada de Agamemnon em Argos. Diante do palácio ele encontra vários símbolos de ostentação de riqueza, colocados lá por sua esposa. O principal destes objetos é uma luxuosa peça de tapeçaria que liga a parte externa ao interior do prédio. Frente ao pedido da esposa para que lá entrasse, Agamemnon reage com preocupação ${ }^{34}$. Não seria uma provocação aos deuses ostentar tamanha riqueza? Por certo que sim, mas o ăv $\alpha \xi$ está muito embriagado por seu orgulho para levar a sério suas próprias palavras. Gernet, ao descrever tal cena, chama atenção para o fato de que, agindo assim, Agamemnon assina definitivamente sua sentença de morte ${ }^{35}$. O capital disponível para a criação de alianças fora aqui gasto desmesuradamente. O rei, que desde a guerra de Tróia fugia de algumas prerrogativas, não consegue mais manter-se enquanto tal. A justiça ( não pode mais chegar aos demais mortais via Agamemnon. Daí sua inevitável derrocada.

Através de Agamemnon e Clitemnestra vimos dois exemplos de uma espécie de cálculo. Por certo, como quer Vernant, estes personagens de uma tragédia não são dotados de uma vontade individual como a nossa. Isso se daria, ainda segundo ele, na forma de um esboço. Ora, até que ponto tal conceito nos equipa para pensarmos o Agamemnon? Existe sim uma escolha. Ela não é construída sobre a idéia de indivíduo, de realização pessoal. Os personagens da tragédia tentam se realizar naquilo que dá sentido para suas vidas: a coletividade. Curioso e emblemático é o desfecho destas ações. É dele que nos ocuparemos na conclusão do presente texto.

\footnotetext{
33 Ag. 1041.

${ }^{34}$ Ag. 906-949.

${ }^{35}$ GERNET, Louis. "La notion mythique de la valeur en Grèce". Op. Cit. pp. 137-138.
} 


\section{A morte de Agamemnon ou como trilhar um caminho para a liberdade}

"A tragédia é o conhecimento básico da unidade de tudo o que existe, a consideração da individualização como causa primeira de todo o mal, a arte como a esperança jubilosa de que possa ser rompido o feitiço da individualização, como pressentimento de uma unidade restabelecida"

Nietzsche

Fez-se, durante todo o presente texto, a tentativa de tentar discutir a ação dentro da tragédia grega. Ora, agindo, os protagonistas constróem sentidos passíveis de serem compreendidos. Resgatar tais experiências deve ser vista como uma das principais possibilidades de extrapolar o próprio texto. Existe alguém atrás do texto. Esse alguém viveu em uma certa época, conheceu problemas específicos e teve de lidar com eles. Através da construção do texto, percebida através dos sentidos da ação dos personagens, é plausível a recuperação do próprio produtor que, conscientemente ou não, interagiu com seus contemporâneos através de seu texto. Seu texto é ação. Mas como percebê-la?

No caso de Ésquilo, o Agamemnon é emblemático. Os personagens principais, signos antigos de um poder não mais presente, sucumbem frente a incapacidade de se sustentarem. Heróis e reis não têm apenas seu significado reatualizado: eles morrem. Mas também não se trata de uma morte pura e simples, nem mesmo de uma eventual ridicularização da condição humana: pode-se perceber um sentido nestas mortes. Qual seria então esse sentido? Minha leitura de Ésquilo sugere como chave o conceito de liberdade. Não obstante, como já foi falado aqui, não se trata de uma liberdade vazia de criatividade e sentido, encerrada no indivíduo incapaz de se envolver e, consequientemente, de assumir responsabilidades. A liberdade para o homem grego é justamente o contrário: assumir a si próprio como limitado e ter consciência de que qualquer escolha depende das possibilidades dadas por outros que estão ao redor. Eis aqui o "si no entre si" de Benveniste, como já foi citado.

Tal luta pela liberdade em Ésquilo pode ser pensada em dois campos complementares: no interior e no exterior do texto. Ora, dentro da peça os protagonistas almejam a liberdade, já que lutam por manter seu espaço de possibilidades frente ao jogo que se lhes apresenta. Agamemnon, por exemplo, sabe como é importante ajudar seus aliados, mesmo tendo de matar sua própria filha. Sacrificá-la, pensando-a como capital, é investir na própria manutenção de sua posição, de sua liberdade. Na peça, porém, existe um paradoxo nas várias tentativas de se alcançar a liberdade. Estas mesmas tentativas desequilibram o próprio jogo, tornando o desfecho dos protagonistas uma constante perda de si. Pensando nestes termos, é curioso o final da Oréstia, trilogia que contém o Agamemnon. Lá Orestes consegue escapar da morte justamente por um elemento novo: um tribunal ateniense 
o absolve. É aqui, neste local, que deuses e homens, em conjunto, tomam alguma decisão e restabelecem uma justiça perdida através da falta trágica.

O final da trilogia é, segundo minha leitura, o grande evento a realizar uma ponte entre a ação dos protagonistas (interna) e a do produtor (externa). Com seu texto Ésquilo parece defender um novo encontro entre homens e deuses. A palavra "novo" aparece aqui justamente porque as formas arcaicas de entrar em contado com estas mesmas divindades ou estão desaparecendo ou estão perdendo seu antigo valor. Abandona-se então a tradição? Não, cria-se a partir dela. Já que não existem mais reis e heróis como existiam na época de Homero, erguem-se novas pontes para com os deuses.

A tragédia grega guarda um poder criativo incomensurável. Por que não pensar as questões trazidas por ela para hoje, principalmente no tocante à compreensão do próprio agir? Não existe (cri)ação sem comprometimento. Não é possível comprometimento sem consciência das próprias limitações. Se tudo hoje nos sugere uma vida frenética, caótica e sem sentido é porque sentimos nesse caminho uma satisfação mais rápida. Nossa liberdade de ação não é ilimitada, nem tampouco termina nos limites do próximo, mas sim na fronteira que cada indivíduo tenta instituir no entre si. Confunde-se tempo com movimento, mas só pode haver movimento se há uma tentativa de interação no mundo. Viver, por si só, está muito além das tradições e do próprio tempo, mas não deixa de primar por uma ética, necessariamente passageira, capaz de suportar a realização de seres tão passageiros como nós. No atual "mundo em crise", somos sempre tentados a sermos indiferentes ou a agarrar-nos a verdades eternas. Não há caminho possível para se criar algo nestas duas opções. É importante resgatar a opção a partir da qual nasce a ação na tragédia esquiliana: seriedade, comprometimento e sensibilidade. 


\section{Bibliografia}

\section{a. TEXTOS ANTIGOS}

ARISTÓTELES. Poética. (Edição Bilíngüe/ Trad. Eudoro de Souza)

São Paulo: Ars Poética, 1993

ÉSQUILO. AESCHYLUS II. Agamemnon, Libation-Bearers, Eumenides and

Fragments. (Edição Bilíngüe/Trad. Herbert Smyth) Cambridge: Harvard

University Press, 1999.

ÉSQUILO. Oréstia. Agamêmon, Coéforas e Eumênides.

(Tradução Mário da Gama Kury) Rio de Janeiro: Jorge Zahar Editor, 1999.

PLATÃO. A República. ( $3^{a}$ edição)

Lisboa: Europa-América, s.d.

\section{b. OBRAS DE REFERÊNCIA}

BAILLY, Anatole. Dictionnaire Grec Français.

Paris: Hachette, 2000-[1894]

BENVENISTE, Émile. O Vocabulário das Instituições Indo-Européias.

(Em 2 Volumes) Campinas: Editora da Unicamp, 1995 - [1971].

DETIENNE, Marcel. Os Mestres da Verdade na Grécia Arcaica.

Rio de Janeiro: Jorge Zahar Editor, 1988 - [1967].

DOODS, E. R. The Greeks and The Irrational.

Londres: Oxford Press, 1986 - [1949].

GERNET, Louis. Anthropologie de la Grèce Antique.

Paris: Flammarion, 1982 - [1968].

Droit et Instituitions en Grèce Antique.

Paris: Flammarion, 1982 - [1968].

LESKY, Albin. A Tragédia Grega.

São Paulo: Perspectiva, 1996 - [1937].

LORAUX, Nicole. Maneiras Trágicas de Matar uma Mulher. Imaginário

da Grécia Antiga. Rio de Janeiro: Jorge Zahar Editor, 1988 - [1985].

MAUSS, Marcel. Sociologia e Antropologia. Volume 2.

São Paulo: Edusp, 1974 - [s.d.]

MOSSÉ, Claude. Grécia Arcaica: de Homero a Ésquilo.

Lisboa: Edições 70, 1989 - [s.d.]

NIETZSCHE, F. W.. O Nascimento da Tragédia.

São Paulo: Cia das Letras, 1999 - [1872].

SISSA, Giulia e DETIENNE, Marcel. Os Deuses Gregos. (Col. A Vida

Cotidiana). São Paulo: Companhia das Letras, 1990 - [1989].

VERNANT, Jean-Pierre. As Origens do Pensamento Grego. ( $9^{\prime \prime}$ edição)

Rio de Janeiro: Bertrand Brasil, 1996 - [1962] 
A Morte nos Olhos. (2" edição)

Rio de Janeiro: Jorge Zahar Editor, 1991 - [1985].

e VIDAL-NAQUET, Pierre. Mito e Tragédia na Grécia Antiga I e II.

São Paulo: Editora Perspectiva, 1999 - [1981]. 